\title{
POLITIK HUKUM PEMBENTUKAN DESA ADAT DALAM SISTEM PEMERINTAHAN DI INDONESIA
}

\author{
Muhammad A. Rauf \\ Fakultas Hukum Universitas Riau \\ Email: muhammadarauf137@gmail.com
}

\begin{abstract}
This study aims to determine the legal political formation of indigenous villages in the government system in Indonesia. Village administration system becomes an important issue in setting the model villages in Indonesia. State recognition of indigenous villages punctuated with the enactment of Law No. 6 of 2014 concerning the village. This study uses normative legal research in which data are collected and analyzed by the sentences associated with existing theories. The results of the study explained that the significance of the state recognizes indigenous villages namely to restore the identity and culture of rural communities, develop and preserve the local wisdom that a system of life of indigenous people of the village and as the controlling influence of globalization that destroys the social culture and Indonesian culture and restore the identity nation. Unification and pluralism to be one cause erosion of the power system and the character of the life of indigenous peoples through policies issued by the State. Therefore it is important to realize the concept of law that characterizes the character and culture of Indonesia in accordance with the times and the law in the society through the instrument of legislation.
\end{abstract}

\section{Kata Kunci: Politik Hukum, Desa Adat, Sistem Pemerintahan.}

\section{A. Latar Belakang}

Sekarang ini telah terjadi perubahan paradigma dalam kehidupan politik dan ketatanegaraan di Indonesia yaitu dari sistem otoritarian kepada sistem demokratis, dan dari sistem sentralistik kepada sistem otonom. Perubahan paradigma tersebut sudah tentu berdampak terhadap sistem hukum yang dianut selama ini yang menitikberatkan kepada produk-produk hukum yang lebih banyak berpihak kepada kepentingan penguasa daripada kepentingan rakyat, dan produk hukum yang lebih mengedepankan dominasi kepentingan Pemerintah Pusat daripada kepentingan Pemerintah Daerah (Romli Atmasasmita 2003: 1).

Perubahan paradigma penyelenggaraan pemerintahan dari sistem sentralisasi menuju sistem desentralisasi menyebabkan terbukanya ruang bagi 
daerah untuk mengurus dan mengatur rumah tangganya sesuai dengan karakteristiknya masing-masing. Atas dasar itu daerah-daerah bisa sajamengambil kebijakan pembenahan sistem pemerintahan sesuai dengan kondisi sosial budaya dan aspirasi masyarakat di daerah.

Secara konstitusional, tindakan itu dibenarkanoleh UUD 1945. Setidaknya, hal tersebut dapat dibaca pada Pasal 18B UUD 1945. Dalam Pasal 18B UUD 1945 dijelaskan bahwa negara mengakui dan menghormati satuan-satuan pemerintahan daerah yang bersifat khusus atau bersifat istimewa. Pengakuan dan penghormatan tersebutsepanjang satuan-satuan masyarakat hukum adat dan hakhak tradisionalnya masih hidup dan sesuai dengan perkembangan masyarakat dan prinsip Negara Kesatuan Republik Indonesia.

Memperhatikan UUD 1945, khususnya dalam bagian penjelasan pasal demi pasal, untuk Bab VI, Pasal 18, maka termuat pengakuan Negara terhadap keberadaan otonomi desa dengan hak asal-usulnya. Dalam bagian penjelasan disebutkan bahwa dalam territorial Negara Indonesia terdapat lebih kurang 250 zelfbestturende lanshappen dan volksgemeenschappen, seperti desa di Jawa dan di Bali, nagari di Minangkabau, dusun dan marga di Palembang dan sebagainya. Daerah-daerah itu mempunyai susunan asli, dan oleh karenanya dapat dianggap sebagai daerah yang bersifat istimewa. Negara Republik Indonesia menghormati kedudukan daerah-daerah istimewa tersebut dan segala peraturan negara yang mengenai daerah-daerah itu akan mengingati hak-hak asal-usul daerah tersebut (Kushandayani, dkk 2011: 67).

Pemerintahan Desa terkait erat dengan keberadaan masyarakat hukum adat di Indonesia yang merupakan sebuah hal keniscayaan yang tidak terbantahkan. Van Vollenhoven dalam penelitiannya pernah menyatakan bahwa masyarakatmasyarakat asli yang hidup di Indonesia, sejak ratusan tahun sebelum kedatangan bangsa Belanda, telah memiliki dan hidup dalam tata hukumnya sendiri. Tata hukum masyarakat asli tersebut dikenal dengan sebutan hukum adat (Hendra Nurtjahjo dan Fokky Fuad 2010: 40).

Upaya memperkuat desa selalu mengalami banyak persoalan, hambatan dan dilema. Hal itu disebabkan oleh beberapa faktor, di antaranya adalah 
mandulnya peran-peran lembaga desa dalam menyambut perubahan yang ada. Beberapa upaya reformasi dan penataan ulang dari semangat dan aturan lama menuju ke semangat dan aturan baru tidak sepenuhnya dapat berjalan mulus. Secara internal Pemerintahan Desa belum menemukan jati diri yang sebenarnya di era otonomi desa, di mana desa merupakan wilayah yang otonom dari Pemerintah yang lebih atas sehingga desa mampu mengambil inisiasi, kreasi dan inovasi sesuai dengan semangat perubahan otonomi yang ada.

Desa adat sebagai masyarakat yang mempunyai tata susunan asli yang sudah lama ada dan sangat perlu dijaga dan dilestarikan eksistensinya. Pengaturan masyarakat hukum adat sesuai dengan ketentuan Pasal 18B ayat (2) untuk diatur dalam susunan pemerintahan sesuai dengan ketentuan Pasal 18 ayat (7) UUD 1945, tetapi kewenangan kesatuan masyarakat hukum adat mengenai pengaturan hak ulayat merujuk pada ketentuan peraturan perundang-undangan sektoral yang berkaitan.

Berdasarkan Pasal 1 Angka 1 Undang-undang Nomor 6 Tahun 2014 tentang Desa, didefenisikan bahwa desa adalah desa dan desa adat atau yang disebut dengan nama lain selanjutnya disebut desa adalah kesatuan masarakat hukum yang memiliki batas wilayah yang berwenang untuk mengatur dan mengurus urusan pemerintahan, kepentingan masyarakat setempat berdasarkan prakarsa masyarakat, hak asal usul dan/atau hak tradisional yang diakui dan dihormati dalam sistem pemerintahan Negara Kesatuan Republik Indonesia.

Keseluruhan hal-hal mendasar yang terkait dengan konstruk pemerintahan desa, tentu berimplikasi terhadap kehidupan masyarakat desa, tetapi disadari bahwa kehidupan desa berada dalam keterhimpitan permasalahan struktur pemerintahan desa, kehidupan perekonomian, dan keterbatasan sumber daya manusia, dan walaupun kehidupan desa memiliki permasalahan itu, ternyata kehidupan desa masih memiliki salah satu keunggulan, yaitu tradisi masyarakat desa serta kultur sosial dan politik menjadi modal sosial (sosial capital) untuk bertahan dalam menghadapi berbagai masalah dan kepentingan dari supra desa.

Keadaan pemerintahan desa sekarang ini adalah sebagai warisan dari undang-undang Lama yang pernah ada untuk mengatur desa, yaitu IGO yang 
berlaku di Jawa dan Madura. Peraturan perundang-undangan tersebut tidak mengatur pemerintahan desa secara seragam dan kurang memberikan dorongan kepada masyarakatnya untuk tumbuh ke arah kemajuan yang dinamis (HAW. Widjaja 2005: 7).

Pelaksanaan dari pengaturan mengenai desa tersebut belum dapat mewadahi segala kepentingan dan kebutuhan masyarakat desa yang hingga saat ini sudah berjumlah sekitar 73.000 (tujuh puluh tiga ribu) desa dan sekitar 8.000 (delapan ribu) kelurahan. Selain itu, pelaksanaan pengaturan desa yang selama ini berlaku sudah tidak sesuai lagi dengan perkembangan zaman, terutama antara lain menyangkut kedudukan masyarakat hukum adat, demokratisasi, keberagaman, partisipasi masyarakat, serta kemajuan dan pemerataan pembangunan sehingga menimbulkan kesenjangan antarwilayah, kemiskinan, dan masalah sosial budaya yang dapat mengganggu keutuhan Negara Kesatuan Republik Indonesia.

Setelah melalui perjuangan panjang akhirnya lahirlah Undang-undang Nomor 6 Tahun 2014 tentang Desa. Undang-undang ini mengakomodir eksistensi desa dan desa adat. Diakui, meskipun disadari bahwa dalam suatu negara kesatuan perlu terdapat homogenitas, tetapi Negara Kesatuan Republik Indonesia tetap memberikan pengakuan dan jaminan terhadap keberadaan kesatuan masyarakat hukum dan kesatuan masyarakat hukum adat beserta hak tradisionalnya.UndangUndang ini menggabungkan fungsi selft governing community dengan local self government, sehingga diharapkan kesatuan masyarakat hukum adat yang selama ini merupakan bagian dari wilayah desa, ditata sedemikian rupa menjadi desa dan desa adat. Oleh sebab itu, menarik dilakukan penelitian terutama mengenai dengan desa adat yang tujuannya untuk mengetahui dan menganalisis urgensi negara membentuk desa adat dalam sistem pemerintahan di Indonesia, serta konsep untuk mewujudkan desa adat dalam sistem pemerintahan di Indonesia.

\section{B. Metode Penelitian}

Penelitian ini akan mengkaji pokok permasalahan sesuai dengan ruang lingkup dan identifikasi masalah melalui pendekatan yuridis normatif. Dalam penelitian normatif ini penulis melakukan penelitian asas-asas hukum yang 
bertitik tolak dari bidang-bidang tata hukum tertentu, dengan cara mengadakan identifikasi terlebih dahulu terhadap kaidah-kaidah hukum yang telah dirumuskan di dalam perundang-undangan. Di dalam penelitian ini penulis mengamati terkait Politik Hukum Pembentukan Desa Adat Dalam Sistem Pemerintahan di Indonesia selanjutnya didukung oleh literatur-literatur yang dibuat oleh para ahli hukum yang terkait dengan masyarakat adat dan Desa Adat.

Analisis yang digunakan adalah analisis kualitatif (HAW.Widjaja 2005: 32), peneliti menerangkan dengan jelas dan rinci melalui interprestasi data dengan menghubungkan keterkaitan data yang satu dengan yang lainnya dan dianalisa berdasarkan teori hukum maupun ketentuan hukum yang berlaku dan pendapat para ahli, untuk kemudian menarik kesimpulan secara deduktif yakni suatu cara penarikan kesimpulan dari hal-hal yang bersifat umum kepada hal-hal yang bersifat khusus (Sudjarwo, MS. 2001: 19).

\section{Hasil Penelitian dan Analisis}

\section{Urgensi pengakuan desa adat dalam sistem pemerintahan di Indonesia}

Pengakuan negara terhadap sistem pemerintahan desa adat yang dalam perkembangannya sangat dipengaruhi oleh produk hukum nasional dalam mengatur kehidupan masyarakat desa adat. Urgensi negara mengakui desa adat dalam sistem pemerintahan di Indonesia yang merupakan cita-cita para pendiri bangsa adalah untuk memberikan kejelasan dari kedudukan dan tujuan terbentuknya desa yang lebih mandiri dengan modal sosial yang kuat. Adapun urgensi negara tersebut dapat dijelaskan dalam beberapa poin berikut:

a. Mengembalikan identitas dan budaya masyarakat pedesaan

Perubahan yang terjadi dalam kehidupan masyarakat meliputi berbagai macam aspek yaitu aspek sosial, budaya, ekonomi, teknologi, maupun ilmu pengetahuan. Aspek-aspek sosial yang penting dalam membentuk pola perilaku kehidupan masyarakat adalah membentuk nilai peradaban yang rasional, adaptasi budaya dan persiapan masa depan masyarakat.

Usaha untuk meningkatkan pembangunan dalam berbagai bidang kehidupan merupakan keharusan yang tidak terelakkan sebagai sebuah negara 
yang sedang berkembang seperti Indonesia. Kemajuan teknologi dan informasi sangat mempengaruhi kehidupan sosial, politik dan budaya masyarakat yang dinamis sesuai dengan perkembangan perubahan di masyarakat. Pola sosial kehidupan masyarakat yang dinamis tersebut akan banyak menghambat pembangunan terutama pada tingkat terendah (semisal desa) apabila tidak dibarengi dengan konsep kebijakan yang pro terhadap kepentingan masyarakat lokal. Oleh karena itu dengan otoritas yang dimiliki negara dalam mengatur kehidupan masyarakatnya maka segala kebijakan terkait dengan masyarakat pedesaan harus diarahkan pada kondisi tempat masyarakat itu hidup dengan prinsip-prinsip yang melekat sebagai sebuah identitas lokal.

Identitas lokal tersebut merupakan ciri khas dari bangsa Indonesia yang telah turun temurun diyakini oleh masyarakat desa sebagai sebuah sistem kehidupan sehingga mesti dipertahankan untuk mengembalikan budaya masyarakat yang begitu sakral agar tidak pudar, dan jika suatu bangsa tidak mempunyai ciri khas atau ciri khasnya telah pudar kerena suatu hal, bangsa tersebut akan mengalami perubahan sikap dan tatanan kehidupan yang terjadi pada masyarakatnya. Masyarakat akan cenderung meniru perilaku atau ciri khas bangsa lain yang diidolakannya, padahal ciri khas bangsa lain belum tentu cocok dan sesuai bila digunakan pada bangsa tersebut. Ketidakcocokan tersebut mungkin dikarenakan faktor letak geografis, kebudayaan, agama yang dianut oleh masyarakat pada umumnya, sejarah pembentukan bangsa, dan sebagainya.

b. Mengembangkan dan melestarikan kearifan lokal

Desa adat menjadi perhatian khusus pemerintah sebagai sarana menumbuhkembangkan dan melestarikan kearifan lokal, adat istiadat dan nilainilai budaya masyarakat Indonesia. Menurut Santoso saat ini eksistensi kearifan lokal dirasakan semakin memudar pada berbagai kelompok masyarakat. Memudarnya eksistensi kearifan lokal tersebut tidak dapat dilepaskan dari kenyataan adanya modernisasi dan globalisasi. Sebagaimana yang dinyatakan oleh Ife dan Tesoriero bahwa untuk menghadapi globalisasi budaya, sangat sulit bagi masyarakat untuk melestarikan budaya lokal mereka sendiri yang menjadi keunikan wilayahnya, sedangkan menurut Sztompka berkaitan dengan pandangan 
modernisasi dan keinginan untuk menyusul masyarakat paling maju, ada kesiapan merangkul pola Barat sebagai cara atau syarat emansipasi masyarakat atau sekurangnya sebagai simbol kemajuan peradaban (Fajar Bagus Ekanda Saputro 2012: 2).

Masih eksisnya kearifan lokal yang dimiliki oleh desa-desa di Indonesia dalam mengelola kehidupan masyarakat desa yang pluralisme tentu tidak terlepas dari adanya upaya-upaya pelestarian. Tanpa adanya upaya pelestarian, besar kemungkinan kearifan lokal tersebut sebagai sebuah tradisi akan musnah dan kehilangan daya mengikatnya bagi masyarakat desa setempat. Sebagaimana yang dinyatakan oleh Sztompka bahwa dalam pengertian yang lebih sempit tradisi hanya berarti bagian-bagian warisan sosial khusus yang memenuhi syarat saja yakni yang tetap bertahan hidup di masa kini, yang masih kuat ikatannya dengan kehidupan masa kini.

c. Sebagai sistem pengendali dari pengaruh globalisasi

Undang-undang Nomor 6 tahun 2014 tentang Desa, secara signifikan telah memberi perubahan terhadap dinamika ketatanegaraan di Indonesia. Undangundang ini secara tegas memberikan kejelasan status desa dalam sistem pemerintahan Republik Indonesia. Kejelasan status memiliki arti penting mengingat ini akan memberikan kemandirian lebih bagi desa untuk mengembangkan potensi lokal, memberikan akses pelayanan publik yang lebih mudah kepada masyarakat, yang pada akhirnya akan memberikan kesejahteraan yang merata bagi masyarakatnya.

Kesejahteraan dan keadilan masyarakat tersebut harus diperhitungkan karena fenomena globalisasi yang tengah melanda Indonesia. Menurut Budi Winarno (dalam http://journal.unair.ac.id/) menegaskan bahwa globalisasi dapat dipahami sebagai perubahan-perubahan dalam bidang ekonomi dan sosial yang berkombinasi dengan pembentukan kesalinghubungan regional dan global yang unik, yang lebih ekstensif dan intensif dibandingkan dengan periode sebelumnya, yang menantang dan membentuk kembali komunitas politik, dan secara spesifik, negara modern. 
Globalisasi telah membuka lebar jalinan interaksi dan transaksi antar individu, kelompok dan antar negara yang membawa implikasi politik, ekonomi, sosial dan budaya beserta Iptek (PEST) pada tingkat dan intensitas yang berbeda (http://sbm.binus.ac.id/files/2013/04/Globalisasi-dan-Indonesia.pdf). Indonesia jelas tidak dapat terlepas dari pengaruh globalisasi yang massif, terlihat dari kecenderungan masyarakat yang lebih memilih untuk menggunakan produk dan kebudayaan asing.

Norma dalam konteks hukum menegaskan globalisasi memberikan pengaruh yang besar, dimana perkembangan Sistem Hukum Indonesia yang cenderung lebih memilih civil law dan common law system dan politik hukum Indonesia yang mengarah pada kodifikasi dan unifikasi hukum (Lastuti Abubakar 2013). Keadaan ini praktis menyebabkan memudarnya peranan pranata hukum adat di Indonesia. Padahal disadari atau tidak, hukum adat merupakan pranata hukum yang justru mampu menangkal pengaruh globalisasi yang bertentangan dengan nilai-nilai luhur maupun hukum positif yang ada di Indonesia.

Globalisasi yang sebagian besar merupakan hasil pemikiran bangsa Barat, tentu tidak dapat sepenuhnya diadaptasi oleh bangsa Timur (termasuk Indonesia) yang juga memiliki budaya serta norma yang secara moril menjadi suatu hal yang harus dijalankan oleh masyarakatnya. Hingga saat ini, pluralisme hukum adat di Indonesia yang tumbuh kembang secara dinamis mengikuti perkembangan masyarakatnya dengan tetap bertumpu pada karakteristik masyarakat adat dan pola pikir participerend coschmish (Lastuti Abubakar 2013).

Pola pikir yang mengedepankan keseimbangan ini diyakini masih relevan untuk diterapkan dalam perkembangan saat ini, karena nyatanya pola pikir ini sangatlah selaras dengan semangat sustainable development atau pembangunan berkelanjutan. Selain itu, memberikan hukum adat ruang untuk tetap ada, berarti juga memberikan keadilan bagi masyarakat hukum adat, karena dengan begitu, dapat memastikan hak-hak masyarakat hukum adat yang diamanatkan konstitusi tetap terjaga, sehingga tidak lagi termaginalkan.

Selain memberikan proteksi, diperlukan juga ruang bagi hukum adat untuk berperan sebagai filter terhadap pengaruh globalisasi yang tidak kompatibel 
dengan tradisi dan budaya Bangsa Timur. Salah satu bukti bahwa peranan masyarakat ada dalam hal ini adalah bagaimana desa adat di Bali terus bertambah dan tetap dengan konsisten menjalankan kegiatan adat, di tengah pesatnya pembangunan objek wisata kelas global di seluruh pulau Bali.

d. Mengembalikan identitas bangsa

Menurut Widianto (2009: 82), berbagai problem mengusik kehidupan berbangsa dan bernegara yang kita hadapi pada saat ini. Salah satunya yaitu adanya isu bahwa semakin banyak kebudayaan bangsa asing yang masuk di Indonesia. Dewasa ini bangsa Indonesia dihadapkan kepada tiga masalah yang saling berkaitan, yaitu (http//:www.unair.ac.id/artikel):

1) Suatu kenyataan bahwa bangsa Indonesia terdiri dari suku-suku bangsa, dengan latar belakang sosio-budaya yang beraneka ragam. Kemajemukan tersebut tercermin dalam berbagai aspek kehidupan. Oleh karena itu diperlukan sikap yang mampu mengatasi ikatan-ikatan primordial, yaitu kesukuan dan kedaerahan.

2) Pembangunan telah membawa perubahan dalam masyarakat. perubahan itu nampak terjadinya pergeseran sistem nilai budaya. Pembangunan telah menimbulkan mobilitas sosial, yang diikuti oleh hubungan antar aksi yang bergeser dalam kelompok-kelompok masyarakat. Sementara itu terjadi pula penyesuaian dalam hubungan antar anggota masyarakat. Dapat dipahami apabila pergeseran nilai-nilai itu membawa akibat jauh dalam kehidupan kita sebagai bangsa.

3) Kemajuan dalam bidang teknologi komunikasi massa dan transportasi, yang membawa pengaruh terhadap intensitas kontak budaya antar suku maupun dengan kebudayaan dari luar. Khusus dengan terjadinya kontak budaya dengan kebudayaan asing itu bukan hanya intensitasnya menjadi lebih besar, tetapi juga penyebarannya berlangsung dengan cepat dan luas jangkauannya. Terjadilah perubahan orientasi budaya yang kadang-kadang menimbulkan dampak terhadap tata nilai masyarakat, yang sedang menumbuhkan identitasnya sendiri sebagai bangsa. 
Identitas asli bangsa Indonesia dapat ditelusuri melalui praktek kehidupan sosial, hukum dan budaya yang paling utama dijadikan rujukan dalam sistem kehidupan masyarakatnya sehingga jati diri bangsa Indonesia yang sesungguhnya tercermin pada perilaku masyarakat Indonesia pada umumnya yang sesuai dengan nilai yang terkandung dalam pancasila. Perilaku yang sesuai dengan nilai dalam pancasila dan merupakan ciri khas bangsa Indonesia yang sesungguhnya.

\section{Konsep mewujudkan desa adat dalam sistem pemerintahan di Indonesia.}

Indonesia sebagai sebuah negara meniscayakan adanya unifikasi hukum. Hal ini menjadi masalah karena pada kenyataannya secara sosiologis Indonesia mempunyai banyak suku-suku yang berbeda di mana sampai saat ini masih memberlakukan hukum adat. Beberapa tahun terakhir pengembangan keberadaan hukum adat justru didukung oleh regulasi nasional maupun internasional. Pendekatan melalui unifikasi hukum ansich disinyalir akan membawa dampak sosio politis, karena secara kasar merusak tatanan yang sudah ada sebelum terbentuknya negara.

Tatkala kehidupan berkembang ke dalam skala-skala yang lebih luas, dari lingkar-lingkar kehidupan komunitas lokal (old societies) ke lingkar-lingkar besar yang bersifat translokal pada tataran kehidupan berbangsa yang diorganisasi sebagai suatu komunitas politik yang disebut negara bangsa yang modern (new nation state), kebutuhan akan suatu sistem hukum yang satu dan pasti amatlah niscaya. Maka gerakan ke arah unifikasi dan kodifikasi hukum terlihat marak di sini, seolah menjadi bagian inheren dari proses nasionalisasi dan negaranisasi serta modernisasi yang amat mengesankan telah terjadinya pengingkaran eksistensi apapun yang berbau lokal dan tradisional (M. Misbahul Mujib 2014: 20).

Gerakan perubahan hukum di Indonesia dengan menggunakan pluralisme hukum sebagai pijakan, telah melangkah cukup jauh. Salah satunya adalah dengan diakuinya hak-hak masyarakat adat, termasuk hukumnya dalam konstitusi. Peraturan yang mengabsahkan berlakunya hukum adat, di antaranya: Peraturan Menteri Dalam Negeri Nomor 3 Tahun 1997 tentang Pemberdayaan dan Pelestarian Serta Pengembangan Adat Istiadat, Kebiasaan-kebiasaan Masyarakat, 
dan Lembaga Adat di Daerah. Undang-undang Dasar 1945 Amandemen, hukum adat diakui sebagaimana dinyatakan dalam Pasal 18B ayat (2) yang menyatakan bahwa negara mengakui dan menghormati kesatuan-kesatuan masyarakat hukum adat beserta hak-hak tradisionalnya sepanjang masih hidup dan sesuai dengan perkembangan masyarakat dan prinsip negara Kesatuan Republik Indonesia, yang diatur dalam undang-undang.

Kemerdekaan Indonesia senafas dengan perkembangan paradigma hukum modern. Menurut Satjipto, hukum modern sarat dengan bentuk-bentuk formal, dan prosedur-prosedur dan dengan penyelenggaraan hukum. sehingga pengaruhnya sangat signifikan (Satjipto Rahardjo 2007: 13). Efeknya hukum yang menjadi tatanan kehidupan masyarakat jauh sebelum kedatangan hukum modern terbuang dari rumah sendirinya. Lebih lanjut Satjipto menguraikan, hukum berubah menjadi instuisi artificial dan makin menjauh dari rakyat atau masyarakat (Satjipto Rahardjo 2007: 13). Bahkan secara ekstrim beliau mengatakan hukum tampil memegang hegemoni dengan hampir membabat habis komunitaskomunitas tatanan yang telah ada jauh sebelum kehadiran hukum modern (Satjipto Rahardjo 2007: 17).

Konsep hukum modern mencirikan pada unifikasi. Konsekuensinya standar perilaku masyarakat diatur secara nasional. Akibatnya karakteristik hukum yang berkeIndonesia-an lenyap diterjang gelombang unifikasi (Soetandyo Widjosoebroto 2002: 255-256). Begitu pula halnya konsep kehidupan masyarakat adat dengan pola kehidupan yang komunal dan integral yang dijiwai oleh masyarakat Indonesia demikian mengalami guncangan yang luar biasa padahal karakteristik masyarakat adat dengan nilai-nilai dan budaya lokal tersebut sebagai bentuk pluralisme hukum yang dianggap sebagai pilihan yang tepat untuk membangun masa depan Indonesia.

Berdasarkan perkembangan yang ada, konsep desa adat sulit untuk dioperasionalkan karena dipengaruhi berbagai pergulatan yang berhubungan dengan konsep unifikasi hukum, pluralisme dan internasionalisasi dalam sistem hukum di Indonesia. Dampak dari unifikasi tersebut membawa perubahan terhadap cara berhukum kita sehingga hakekat keberadaan hukum sering dicerabut 
atau dilupakan dari manusianya, padahal setiap masyarakat memiliki karakter, nilai-nilai yang berbeda, yang semestinya hukum harus mengikuti lingkungan dan masyarakatnya. Membicarakan hukum Indonesia berarti membicarakan masyarakat Indonesia, tidak mungkin membicarakan masyarakat Barat, Timur Tengah atau negara lainnya (Firdaus 2011: 111).

Hasil dari semua itu saat ini ada tiga produk hukum yang hidup dalam masyarakat Indonesia yaitu hukum negara, hukum Agama, dan hukum adat, karena ketiganya sudah diakui secara kontitusional. Artinya masyarakat Indonesia diberi kebebasan untuk menggunakan di antara tiga produk hukum itu. Sistem hukum yang mana yang dianut oleh masing-masing negara di dunia ini dapat dilihat atau temukan pada masing-masing dasar falsafah atau pandangan hidup bangsa yang bersangkutan dan bagaimana aturan-aturan hidup mereka dalam menyelesaikan suatu masalah hukum. Setiap negara berbeda-beda dasar falsafah hidupnya ataupun pandangan dan sikap hidupnya serta kultur atau budaya bangsanya, oleh sebab itu hukumnya pun berbeda, sebab hukum itu adalah sebagian besar tumbuh dari kebudayaan suatu bangsa (Soetandyo Widjosoebroto 2002: 255-256).

\section{Simpulan dan Saran}

\section{Simpulan}

Berdasarkan hasil pembahasan Penulis di atas, maka dapat disimpulkan bahwa desa merupakan salah satu entitas politik yang memiliki peran strategis dalam mencapai tujuan kesejahteraan bagi bangsa Indonesia. Urgensi Negara mengakui desa adat yaitu, (a) mengembalikan identitas dan budaya masyarakat pedesaan, (b) mengembangkan dan melestarikan kearifan-kearifan lokal yang merupakan sistem kehidupan masyarakat asli desa, (c) sebagai pengendali pengaruh globalisasi yang dapat menghancurkan kebudayaan sosial dan budaya masyarakat Indonesia, dan (d) mengembalikan identitas bangsa.

Konsep unifikasi menjadi salah satu penyebab tergerusnya sistem kekuatan dan karakter kehidupan masyarakat adat melalui kebijakan-kebijakan yang dikeluarkan oleh Negara. Oleh karenanya penting mewujudkan konsep 
hukum yang mencirikan watak dan budaya masyarakat Indonesia sesuai dengan perkembangan zaman dan hukum yang hidup dalam masyarakat. Dalam perkembangannya konsep desa adat sulit untuk dioperasionalkan karena dipengaruhi berbagai pergulatan yang berhubungan dengan konsep unifikasi hukum, pluralisme dan internasionalisasi dalam sistem hukum di Indonesia.

\section{Saran}

Kepada Pemerintah Daerah Provinsi, Kabupaten/Kota diharapkan benarbenar memperhatikan kondisi desa yang memiliki karakteristik pemerintahan adat dan dapat merealisasikan konsep desa adat di daerahnya sesuai dengan perintah Undang-undang Nomor 6 Tahun 2014 tentang Desa sekaligus melakukan pembinaan dan pengawasan yang intensif terhadap pelaksanaan tugas yang dijalankan oleh masing-masing desa.

Kepada Lembaga-Lembaga adat, para akademisi yang ada di daerah agar lebih berperan aktif untuk memberikan masukan dan saran kepada pemerintah daerah dalam menata sistem pemerintahan desa terutama model desa adat yang relevan dengan perkembangan zaman 


\section{DAFTAR PUSTAKA}

\section{Buku:}

Abdulkadir Muhammad. 2004. Hukum dan Penelitian Hukum. Bandung: Citra Aditya Bakti.

Aliziduhu Ndraha. 1991. Dimensi-dimensi Pemerintahan Desa. Jakarta: PT Bumi Aksara.

Ateng Syafrudin dan Suprin Na'a. 2010. Republik Desa, Pergulatan Hukum Tradisional dan Hukum Modern Dalam Desain Otonomi Desa. Bandung: Alumni.

Bagir Manan. 2001. Menyongsong Fajar Otonomi Daerah. Cetakan I. Yogyakarta: Pusat Studi Hukum FH UII.

Bambang Trisantono Soemantri. 2011. Pedoman Penyelenggaraan Pemerintahan Desa. Bandung: Fokus Media.

Dharmayuda. 2001. Desa Adat Kesatuan Masyarakat Hukum Adat di Bali. Denpasar: Upada Sastra.

Hanif Nurcholis. 2005. Teori dan Praktek Pemerintahan dan Otonomi Daerah. Jakarta: Gramedia Widiasarana Indonesia.

Hendra Nurtjahjo dan Fokky Fuad. 2010. Legal Standing Kesatuan Mayarakat Hukum Adat, dalam berperkara di Mahkamah Konstitusi. Jakarta: Salemba Humanika.

Jimly Asshidiqie. 2008. Menuju Negara Hukum yang Demokratis. Jakarta: Sekretariat Jenderal dan Kepaniteraan Mahkamah Konstitusi.

Kaho Josef Riwu. 2012. Analisis Hubungan Pemerintah Pusat dan Daerah. Yogyakarta: JPP Press.

Mashuri Maschab. 2013. Politik Pemerintahan Desa Di Indonesia. Cetakan I. PolGov. Fisipol UGM. Yogyakarta.

Moh. Mahmud MD. 2009. Politik Hukum di Indonesia. Jakarta: PT. RajaGrafindoPersada.

Muhammad Yasin (dkk). 2014. Anotasi Undang-undang Nomor 6 Tahun 2014 tentang Desa. Jakarta: Pusat Telaah dan Informasi Regional (PATTIRO).

Ni'matul Huda. 2015. Hukum Pemerintahan Desa dalam Konstitusi Indonesia Sejak Kemerdekaan Hingga Era Reformasi. Yogyakarta: Setara Press.

Otje Salman Soemadiningrat, R. 2002. Rekonseptualisasi Hukum Adat Kontemporer. Bandung: Alumni. 
Ratno Lukito. 1998. Pergumulan Antara Hukum Islam dan Adat di Indonesia. Jakarta: INIS.

Soerya Respationo, H.M. 2012. Buku Ajar Politik Hukum. Bandung: Citapustaka Media Perintis.

Soetardjo Kartohadiekoesoemo. 1984. Desa. Jakata: Balai Pustaka.

Suhartono (dkk). 2001. Politik Lokal. Yogyakarta: Penerbit Lapera.

Sutoro Eko. 2005. "Masa Lalu. Masa Kini dan Masa Depan Otonomi Desa" dalam Soetandyo Wignosubroto (dkk). Pasang Surut Otonomi Perjalanan 100 Tahun Daerah. Sketsa. Jakarta: Institute for local development dan Yayasan Tifa.

Wasistiono Sadu dan Irwan Tahir. 2007. Prospek Pengembangan Desa. Bandung: Fokusmedia.

Widjaja, H.A.W. 2002. Pemerintahan Desa/Marga: Berdasarkan Undang-undang Nomor 22 Tahun 1999 tentang Pemerintahan Daerah (Suatu Telaah Administrasi Negara). Jakarta: PT. RajaGrafindo Persada.

-. 2008. Otonomi Desa Merupakan Otonomi yang Bulat dan Utuh. Jakarta: PT.RajaGrafindo Persada.

Yando Zakaria, R. 2000. Abih Tandeh. Masyarakat Desa di Bawah Rejim Orde Baru. Jakarta: ELSAM.

\section{Laporan Penelitian, Jurnal dan Artikel:}

Bhenyamin Hossein. 2006. “Arah Kebijakan Pembangunan Hukum di Bidang Penyelenggaraan Desentralisasi dan Otonomi Daerah (Hubungan Kewenangan Antara Pusat dan Daerah)". Makalah. Disampaikan pada Seminar Arah Pembangunan Hukum Menurut UUD 1945 Hasil Amandemen. Jakarta. 29-31 Mei.

Hanif Nurkholis. 2014. "Tantangan dan Prospek Implementasi UU No. 6/2014 tentang Desa". Makalah. Disampaikan dalam Seminar Nasional Administrasi Negara di FISIP Universitas Negeri Padang. 13 November.

Kushandajani. 1991. "Elit Desa ditinjau dari Sumberdaya Kekuasaan”. Tesis. Jakarta: Megister Ilmu Politik Universitas Indonesia.

Kushandayani (dkk). 2011. "Studi Evaluasi Penyelenggaraan Pemerintahan Desa Berdasarkan UU No.32 Tahun 2004 tentang Pemerintahan Daerah. Jurnal Bhineka Tunggal Ika. Volume 2. No. 2.

Romli Atmasasmita. 2003. "Menata Kembali Masa Depan Pembangunan Hukum Nasional". Makalah. Disampaikan dalam Seminar Pembangunan Hukum Nasional VIII yang diselenggarakan oleh Badan Pembinaan Hukum 
Nasional. Departemen Kehakiman dan Hak Asasi Manusia RI. Denpasar. 14-18 Juli.

Zen Zanibar, M.Z. 2003. "Otonomi Desa dengan Acuan Khusus pada Desa di Provinsi Sumatera Selatan. Disertasi. Jakarta: Program Pascasarjana Fakultas Hukum Universitas Indonesia.

Zudan Arif Fakrulloh. 2014. "Kedudukan dan Penetapan Desa dan Desa Adat Berdasarkan Undang-undang Nomor 6 Tahun 2014 tentang Desa”. Jurnal Hukum 'Inkracht'. Volume I. Nomor 1. Nopember. Jakarta: Program Pascasarjana Universitas Borobudur.

\section{Peraturan Perundang-undangan:}

Republik Indonesia, Undang Undang Dasar Tahun 1945

Republik Indonesia, Undang-undang Nomor 32 Tahun 2004 tentang Pemerintahan Daerah.

Republik Indonesia, Undang-undang Nomor 23 Tahun 201, tentang Perubahan Undang-undang Nomor 32 Tahun 2004 tentang Pemerintahan Daerah.

Republik Indonesia, Undang-undang Nomor 6 Tahun 2014 tentang Desa 


\section{BIODATA PENULIS}

$\begin{array}{ll}\text { Nama } & \text { : Muhammad A. Rauf } \\ \text { Pekerjaan } & \text { : Mahasiswa Program Pascasarjana Fakultas Hukum Universitas } \\ & \text { Riau } \\ \text { Jabatan } & :- \\ \text { Nomor HP } \quad:- & \\ \text { E-mail } & : \text { muhammadarauf137@gmail.com } \\ \text { Alamat Kantor } & \text { : Kampus Bina Widya Km 12.5, Simpang Baru Pekanbaru- }\end{array}$ 28293 